\title{
Features of the Formation and Development of the Region's Human Capital in a Digital Transformation
}

\author{
Muslim Ibrahimov ${ }^{1}$ N.A. Gerasimova² A.N. Kogteva ${ }^{2}$ A.M. Kulik ${ }^{2, *}$ \\ E.P. Druzhnikova ${ }^{2}$ \\ ${ }^{1}$ University of Siegen, Siegen, North Rhine-Westphalia, Germany \\ ${ }^{2}$ Department of Applied Economics and Economic Security, Belgorod State National Research University, Belgorod,
} Russia

"Corresponding author.Email: kulik@bsu.edu.ru

\begin{abstract}
At present, humanity is living in conditions of a digital transformation. The scientific and technological revolution has been replaced by an informational (digital) revolution, during which a new "information society" is being created. With the digitalization of the regions, highly educated, professionally trained human capital is gaining more and more value. Digital transformation changes a person's life, forms a virtual and augmented reality built into ordinary everyday life. The digital environment, acting on the mechanism of the formation of human capital in the region, complicates its structure, adding new characteristics, presents new requirements for human capital, and poses new challenges for the region related to the formation of human capital, the solution of which will increase its economic growth.
\end{abstract}

Keywords: regional economy, human capital, digital economy, transformation, forms of human capital,

competencies

\section{INTRODUCTION}

At the beginning of the third millennium, the national wealth of all countries of the world by Russian scientists was estimated at $\$ 550$ trillion, of which half were in the most developed countries (USA, UK, France, Germany, Italy, Canada, and Japan). More than half of the world's national wealth was human capital - 365 trillion dollars, reproducible and natural capital accounted for 95 and 90 trillion dollars, respectively. Updating strategic documents of the social and economic development of Russia takes place in crisis conditions, it is necessary to search for a new non-resource model of regional economic growth, the goal which would be the diversification of its structure by accumulating human capital, borrowing and developing new technologies, creating conditions for investment and business.

At the same time, the economic development trends of recent years have shown that not only quantitative assessments of human capital, but also its qualitative content are changing, the structure is becoming more complicated, and the life cycle of human capital is changing. Under these conditions, the study of the integrated impact of the digital economy on the processes of evolution of human capital, which acts as the epicenter of the ongoing global technological transformations, is of particular relevance.

In the context of digital transformation, the content, structure, cyclic phases, stages of reproduction and quantitative characteristics of the region's human capital are changing, the analytical algorithm and applied tools for complex indication of the dynamics and structure of human capital, and the algorithm for determining priority directions of the region's human capital reproduction in digitalization are becoming more complicated.

The scientific problem of the study is the contradiction between the need to ensure digital transformation of social and economic processes in the regions, which requires significant investments in the individual as a carrier of human capital and, accordingly, high returns on his activities, the emergence and development of new forms, a change in approaches to its assessment, and the lack of theoretical and methodological conceptual foundations of the study of evolution and applied tools for assessing and modeling regional human capital in a parade the game of the digital economy.

This problem is exacerbated by the exhaustion of opportunities for extensive economic growth based on the exploitation of regional raw materials, against the backdrop of the emergence of a limited group of leading countries with new production technologies and focused on the use of renewable resources; as well as the demographic transition, due to an increase in the life expectancy of people, a change in their lifestyle, and the associated aging of the population, which together leads to new social and economic problems.

The coherent, integration and variant impact of the digital economy on the human capital of a region is manifested in the complexity of its structure, changes in its life cycle, intellectualization, creativity, commercialization, virtualization, divergence of techno genesis and anthropogenesis, requires a theoretical and methodological 
justification of the conceptual foundations and analysis of factors affecting efficiency the functioning of regional human capital in the context of digitalization.

\subsection{Related Work}

Recently, estimates of the leading role of human capital in modern socio-economic development have become widespread in the scientific literature. A significant breakthrough in the scientific study of the problems of the intellectual economy takes place at the turn of the 19501960s. and is associated with the formulation of the theory of human capital in the classical works of T. Schultz and G. Becker [1,2], and a little later, J. Ben-Porath,, B. Chiswick, D. Mincer, L. Thurow [3,4,5,6]. This theory arose based on a long development of human-oriented problems in economic science. In modern Russian theoretical literature, various aspects of the theory of human capital are developed in the works of scientists of the St. Petersburg school: A.I. Dobrynina, S.A. Dyatlova [7.8], I.V. Ilyinsky [9], S.M. Klimova [10], B.V. Korneichuk [11], M. M. Kritskii [12], L.G. Simkina [13]. A large number of studies are devoted to the study of the essence of the digital economy. Nicholas Negroponte [14] presented the ideology of the concept in 1995. Features of the digital development of the economy are considered in the works of both foreign and domestic scientists and researchers. According to I.V. Mitrofanova, the digital economy is a system of economic, social and cultural relations, which are based on digital technology [15]. L.D. Kapranova connects the concept of "digital economy" with a set of economic and social activities that are provided by information and communication technologies, such as the Internet, mobile and sensor networks, including communications, financial transactions, education, entertainment and other types of business based on the use of computers, smartphones and other devices [16].

In the context of the digital economy, human capital is evolving, changing its meaningful characterization, since the digital transformation of the economy implies that a person has certain types of properties that are in demand in an innovative economy. Considering the process of development of the region from the perspective of the socio-economic aspect, it can be concluded that one of the main factors playing one of the key roles in the context of digital transformation is human capital.

Human capital, in transformational conditions, is a combination of the main quantitative and qualitative parameters, which are formed due to its main forms, which include social and economic, physical, intellectual, information and communication forms. Digital transformation poses new challenges for the development of human capital in the regions. Under these conditions, human capital acts as a fundamental factor, which, depending on the situation, can lead to either an increase or a decrease in the digital transformations of the region.

We believe that a new component is emerging that defines the regional features of the development of human capital the digital environment. An environment that creates the conditions for the development of platforms and technologies and the effective interaction of regional market entities and sectors of the regional economy (fields of activity) and, as M.N. Osovin, "covers regulations, information infrastructure, human resources and information security" [17].

According to the generation type of assumptions, we divided the existed work into two categories.

\subsection{Paper Structure}

In this article, we present the characteristics of the main forms of human capital; determine the impact on the components of human capital of digital transformation. We will determine the main factors affecting the decrease in the efficiency of the formation and development of the intellectual and information and communication forms of human capital in the region, as the most important forms of human capital formation in the context of digital transformation. As a result, we will determine the main ways of forming and developing the human capital of the region in the context of digital transformation.

\section{BACKGROUND}

In the current conditions of the functioning of the region, the digital environment affects the development of regional human capital, creates and affects the development of the information and communication form of regional human capital, and impacts on the educational, socio-economic, natural and climatic environment. It creates the conditions for the qualitative development of the other three forms of human capital - intellectual, socioeconomic, physical (Figure 1).

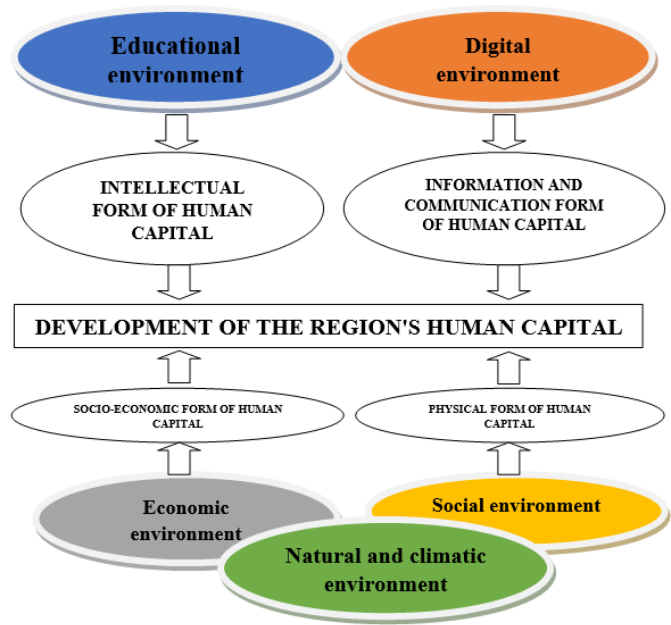

Figure 1. A model for the development of human capital in a region in the context of digital transformation

It should be noted that the information, communication, and intellectual form are closely interrelated, and it is these forms that are more affected by the development of the digital economy of the region. The socio-economic form of the region's human capital is a combination of the main characteristics characterizing the development efficiency and profitability of human capital. 
The physical form of the region's human capital is a characteristic that reveals the features of the conservation of human capital, affecting its quantitative parameters.

The intellectual form of human capital in the region characterizes the intellectual components of human capital, the level of knowledge.

The information and communication form of human capital characterizes the ability of the region's human capital to expand its level of knowledge and increase intellectual abilities. In the new economic conditions, this is one of the main constituent groups of human capital, since it characterizes the use by the population of the region of the potential of new information technologies (mobile applications, Internet technologies, cloud services, etc.).

The digital environment affects the development of regional human capital; it creates the conditions for the qualitative formation of human capital. The digital environment is interconnected with the educational environment, since in the digital economy there is a shift in emphasis from physical to intellectual work, which leads to a situation of a constant increase in the educational level of the able-bodied population of the region. We agree with the opinion of O.S. Sukharev [18] that this educational process should be a practically nonstop process. This is very relevant precisely in the context of digitalization of society. A. Chukhno [19] notes that it is the development and rise of the level of education, the use of intellectualization of labor, the enrichment of people with knowledge that underlie the growth of human capital. This increase is not only aimed at the growth of the population with higher education, it is accompanied by large structural shifts in the economy.

However, it should be noted that, considering the regional features of the development of human capital in the context of digital transformation, we noted that the formation of basic environments, which, in turn, form the main forms of regional human capital, is quite uneven. It depends on the specifics of the region, on the characteristics of the development of the region, on the main factors influencing the formation of the economic, climatic, social, educational and digital environment, on the features of the development of digitalization in the region.

As part of the study, we will focus on two components of the formation of the region's human capital, namely the intellectual and information and communication form, since, in our opinion, the digital economy has the greatest impact on them. Thus, influencing the formation and development of human capital in the region.

The main factors affecting the decrease in the efficiency of the formation and development of the intellectual form of human capital in the region are:

1. Lack of qualified personnel and the need for adjustments in educational programs. For example, in order for the share of IT professionals to reach $4.3 \%$, as in developed countries, it is necessary to provide an additional influx into the digital economy of two million IT professionals. The most acute issue with personnel is in high-tech industries involving international cooperation. The lack of qualified personnel is also associated with the migration outflow of the population from the region. Therefore, the formation of the physical form of human capital is associated with the preservation and growth of the amount of labor resources of the region's population. This is one of the main forms of development of human capital in the region, since only the able-bodied part of the population, which has all the necessary physical capabilities, and which can carry a certain level of intelligence, creative and creative abilities, which in turn will increase the competitive advantages of the region, as the authors note [20]. During the first decade of the 21st century, our state lost a significant share of human capital because of migration to more prosperous countries. According to some estimates, during the first decade of the XXI century. The outflow of specialists with higher education amounted to about 1 million people [21]. At the same time, Russian specialists in the field of IT technologies, due to the specifics of their professional competencies, quickly found themselves on the crest of migration processes.

We agree with the opinion of M.E. Baskakova and I.V. Soboleva [22] that the development of the digital economy also contributes to the fact that, along with the physical departure of specialists to countries with more favorable conditions, a powerful "brain drain" also constitutes a powerful channel for the depletion of human capital.

2. In the context of digital transformation, the intellectual form of the region's human capital is becoming more complicated.

The introduction of digital technology leads to significant changes in staffing requirements and requirements for specialists in the region:

- reduced demand for professions related to formalized repetitive operations;

- shortening the life cycle of professions in connection with the rapid change of technology;

- transformation of competency profiles of certain categories of personnel (risk analytics, HR managers, marketing analysts, contact center operators, etc.) in connection with a change in the work tools;

- the emergence of new roles and professions;

- increasing the requirements for flexibility and adaptability of staff;

- increased requirements for "soft skills" - the possession of social and emotional intelligence, i.e. ultimately those abilities that distinguish a person from a machine;

- The growing demand for professionals with "digital dexterity".

The increasing penetration of algorithms and computer solutions will lead to a reorientation of the needs of the labor market to "human in man": creativity, cultural aspects, individual and collective values, and the need for categories of the able-bodied population of the region to realize universal "competencies of the 21 st century" will increase.

According to research [23], at present, the specialties of the able-bodied population are divided into 3 categories. We believe that in the context of digital transformation, the set of competencies implemented by each presented category is complicated (Fig. 2), which in turn leads to a more complicated structure of the region's human capital. Cognitive skills include self-development (learning ability, perception of criticism), organization (resource management), managerial skills (prioritization, team building, motivating others), achieving results (risk taking, 
initiative), solving non-standard tasks (creativity, critical thinking), adaptability (work in conditions of uncertainty). Socially behavioral skills require the following competencies: communication (presentation, writing, negotiation skills), interpersonal abilities (work as well as a team, stress management, empathy), intercultural interaction (social responsibility, cross-functional interaction and krossdistsiplinarnoe, foreign languages). Digital skills: creating systems (programming, application development, ICT skills), information management (data processing and analysis).

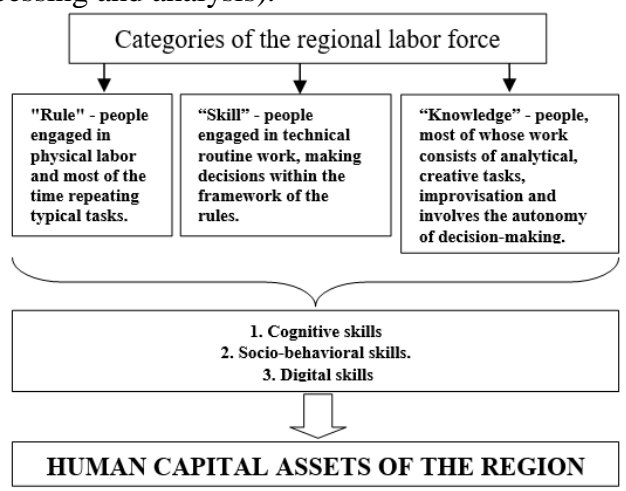

Figure 2. The competency formation scheme of the labor force, forming the human capital assets of the region, in the context of digital transformation

According to studies, at present the largest number of ablebodied people dominates in the regions namely the "Rule" and "Skill" categories - up to $83 \%$ of the total population [23]. The implementation of core competencies in these categories is shown in Figure 3.

That is, we can conclude that the regions need a retraining of the working population. This process requires a reorientation of the education system, taking into account the requirements of digital transformation. Since today the education system does not train personnel for the knowledge economy, as higher education "has lost quality, but has become universal". From 1993 to 2015, the number of university places more than doubled with a $36 \%$ reduction in the number of applicants; there was no postgraduate education system.

Regular updating of competencies after graduation from an educational institution is not organized, study in the process of work is either formal, or is aimed at "pinpointing the gaps in the education system" [23].

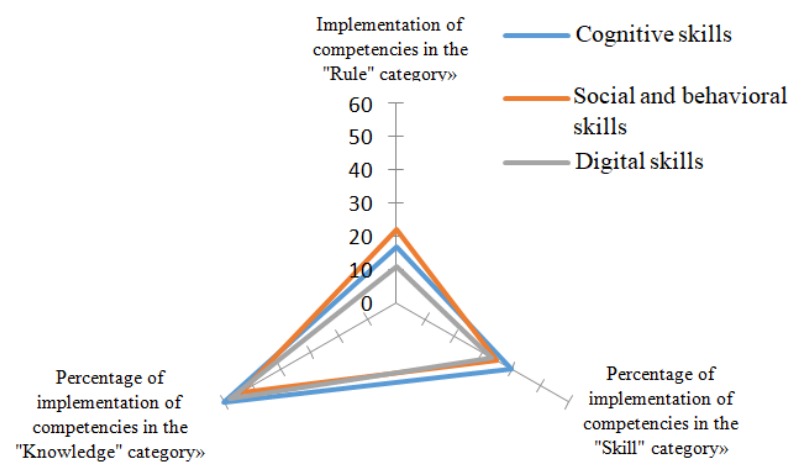

Figure 3. Implementation of core competencies by categories of the region's labor force
3. The problem is that wages in Russia do not stimulate highly qualified professions, as a result, there is not a sufficiently high demand for knowledge, and the prestige of professions requiring complex training is low.

Considering the information and communication form of the region's human capital, it can be noted that this form is expressed through investing in the acquisition of capitalized network abilities, skills and competencies of the regional labor force, used for effective interaction via the Internet with network government structures, with network business structures, scientific networks educational communities and with social networks that are used to receive various social benefits, market advantages and network effects.

The main factors affecting the decrease in the effectiveness of the formation and development of the information and communication form of human capital in the region are: 1. The presence of digital inequality. Conducting an analysis of many factors affecting the level of digitalization of regions, we can conclude that there is a digital gap in the regions of the Russian Federation. For example, evaluating access to the Internet system, we can find a certain contradiction. While there is an increase in the number of active users by districts and regions of the Russian Federation (Table 1), we still have a gap in network connectivity by region. For example, the least number of connections is observed in the regions of the Far East and the North Caucasus region and in the Volga region even, a decrease in the growth rate by $1.26 \%$ is observed.

Without access to the Internet, it is impossible to use either government services or the services of "smart cities".

There are still quite a few problems, especially in the lagging regions of the Russian Federation, with the introduction of modern standards for cellular communications; the use of cellular communication devices in the regions of the Russian Federation is declining (Table 2).

Only a third of cellular base stations support the modern standard of mobile Internet - 4G and LTE.

The implementation of the $5 \mathrm{G}$ standard has been postponed until 2022.

Table 1. The number of active subscribers of fixed Internet access, units [24]

\begin{tabular}{|l|c|c|c|}
\hline $\begin{array}{c}\text { District of the } \\
\text { Russian Federation }\end{array}$ & $\mathbf{2 0 1 8} \mathbf{\Gamma .}$ & $\begin{array}{c}\mathbf{2 0 1 9} \mathbf{~} \mathbf{.} \\
\mathbf{( 3 ~ q u a r t e r})\end{array}$ & $\begin{array}{c}\text { Growth } \\
\text { ratio, \% }\end{array}$ \\
\hline $\begin{array}{l}\text { Central Federal } \\
\text { District }\end{array}$ & 10173553 & 10452782 & 2,7 \\
\hline $\begin{array}{l}\text { Northwestern Federal } \\
\text { District }\end{array}$ & 3361681 & 3398603 & 1,09 \\
\hline $\begin{array}{l}\text { Southern Federal } \\
\text { District }\end{array}$ & 2961501 & 3135207 & 5,8 \\
\hline $\begin{array}{l}\text { North Caucasus } \\
\text { Federal District }\end{array}$ & 852959 & 920836 & 7,9 \\
\hline Volga Federal District & 6494139 & 6412285 & $-1,26$ \\
\hline Ural federal district & 3054959 & 3110256 & 1,8 \\
\hline $\begin{array}{l}\text { Siberian Federal } \\
\text { District }\end{array}$ & 3495751 & 3533952 & 1,04 \\
\hline $\begin{array}{l}\text { Far Eastern Federal } \\
\text { District }\end{array}$ & 1441196 & 1479289 & 2,6 \\
\hline
\end{tabular}


Table 2. The number of subscriber devices for mobile radiotelephone (cellular) communication, per 1000 population, at the end of the year, units. [24]

\begin{tabular}{|l|c|c|c|}
\hline \multicolumn{1}{|c|}{$\begin{array}{c}\text { District of the Russian } \\
\text { Federation }\end{array}$} & $\mathbf{2 0 1 7} \mathbf{\Gamma} \cdot$ & $\mathbf{2 0 1 8} \mathbf{~} \boldsymbol{~}$ & $\begin{array}{c}\text { Growth } \\
\text { ratio, \% }\end{array}$ \\
\hline Central Federal District & 2409,9 & 2364,7 & $-1,87$ \\
\hline $\begin{array}{l}\text { Northwestern Federal } \\
\text { District }\end{array}$ & 2358,7 & 2251,2 & $-4,55$ \\
\hline Southern Federal District & 1787,2 & 1746,5 & $-2,27$ \\
\hline $\begin{array}{l}\text { North Caucasus Federal } \\
\text { District }\end{array}$ & 1371,5 & 1331,3 & $-2,93$ \\
\hline Volga Federal District & 1851,5 & 1843,2 & $-0,44$ \\
\hline Ural federal district & 1905,5 & 1954,7 & 2,58 \\
\hline Siberian Federal District & 1832,4 & 1805,8 & $-1,45$ \\
\hline Far Eastern Federal District & 1681,4 & 1623,1 & $-3,46$ \\
\hline
\end{tabular}

2. The lack of the development of information infrastructure in the regions, including the use of end-toend digital technologies for the following solutions: automated control of equipment loading, fuel consumption, stability of technical systems, employee fatigue, automated process and safety management, robotics, implementation of remotely controlled equipment, automated analytics collection, systems availability predictive analytics.

3. The level of implementation of digitalization in the regions of the Russian Federation varies significantly. For clarity, the results of the study of 85 subjects of the Russian Federation can distinguish only 10 leaders in terms of digitalization.

On a 100-point scale, the interval of the Digital Russia index indicators in the first half of 2018 narrowed and ranged from 37.2 to 75.14 points (in 2017 , this interval was 26.06-70.01). This result indicates a reduction in the gap between leading and trailing rating subjects of the Russian Federation. Sevastopol, the Pskov region, the Republic of Adygea (Adygea), the Republic of North Ossetia-Alania, the Chukotka Autonomous Region, the Republic of Kalmykia, the Karachay-Cherkessia Republic, the Republic of Tyva, the Republic of Ingushetia, and the Jewish Autonomous Region are included in the Rating (Table 3) [23].

Table 3. Leading regions in terms of digitalization [23]

\begin{tabular}{|l|c|c|c|}
\hline $\begin{array}{l}\text { The subject of } \\
\text { the Russian } \\
\text { Federation }\end{array}$ & $\begin{array}{c}\text { The value of the } \\
\text { digitalization index } \\
\text { for the first half of } \\
\mathbf{2 0 1 8}\end{array}$ & $\begin{array}{c}\mathbf{2 0 1 7} \\
\text { Digitalization } \\
\text { Index Value }\end{array}$ & $\begin{array}{c}\text { Growth } \\
\text { ratio, \% }\end{array}$ \\
\hline Moscow & 75,14 & 70,01 & 7,33 \\
\hline $\begin{array}{l}\text { Republic of } \\
\text { Tatarstan }\end{array}$ & 74,74 & 67,95 & 9,99 \\
\hline St. Petersburg & 74,55 & 67,54 & 10,38 \\
\hline KhMAD Yugra & 74,24 & 67,88 & 9,37 \\
\hline Tyumen region & 74,01 & 65,44 & 13,10 \\
\hline $\begin{array}{l}\text { Yamalo-Nenets } \\
\text { Autonomous } \\
\text { Okrug }\end{array}$ & 72,43 & 66,03 & 9,69 \\
\hline $\begin{array}{l}\text { Moscow region } \\
\text { Republic of } \\
\text { Bashkortostan }\end{array}$ & 71,86 & 65,61 & 9,53 \\
\hline $\begin{array}{l}\text { Leningrad } \\
\text { region }\end{array}$ & 71,29 & 65,08 & 9,54 \\
\hline $\begin{array}{l}\text { Chelyabinsk } \\
\text { region }\end{array}$ & 70,75 & 62,45 & 14,09 \\
\hline
\end{tabular}

The results of the study at the level of federal districts show the same trend as at the level of constituent entities of the Russian Federation. At the same time, at the level of federal districts, this process is more dynamic, and the gap between the values of the Digital Russia index between leaders and closers is less than in the subjects of the Russian Federation. The decrease in the standard deviation of the index by federal districts amounted to $3.4 \%$, respectively.

We focus on the fact that most of the regions began to engage in digitalization before the introduction of the unified state program "Digital Economy of the Russian Federation", therefore, some of the effects reflected in the index values could be medium and long-term effects from initiatives implemented before 2018. Moreover, since the Digital Economy of the Russian Federation program is designed until 2024, and with each year, the complexity and number of tasks to be solved will increase, it is expected that the rate of change in the index and the level of digitalization in the regions will be lower.

Thus, the digital economy program opens up new opportunities for the regional economy, and, in particular, opportunities for the development of human capital. The development of innovative industries creates new jobs for highly skilled professionals. At the same time, this is also a challenge for the regions, which must solve the problems of effective training of qualified personnel and attracting professionals to their enterprises. For this, it is important for the regions to determine priority sectors, maintain the necessary educational base, and eliminate the digital gap.

The main ways of formation and development of human capital in the region in the context of digital transformation are as follows:

- the opportunity for regions to maintain competition in the global economy is the implementation of a scenario of advanced modernization of a qualitative change in the labor market and an increase in the share of highly qualified professionals, by introducing a system of retraining of the released staff.

- the educational system should be restructured so that it prepares workers of the "Knowledge" category at a faster pace, a change in the institutional and economic model of education is necessary;

- educational programs require reorientation from the development of subject knowledge and memorization of information to the development of personal and metasubject competencies. Unusual types of education are needed to maintain the competitiveness of natural intelligence compared to artificial;

- a system of stimulating professional growth and obtaining new knowledge is needed;

- the introduction of a neural network education system that will provide training for personnel with network competencies and will rely on neurocognitive mechanisms for acquiring new knowledge, the use of neurocomputer interfaces, elements of virtual and augmented reality, and hybrid intelligence. Currently, the products and services of the neural network education market are developing in such segments as distance learning, lifelong learning, massive open online courses, blended learning, innovative models of continuing education, as well as the full use of integrated systems of natural and artificial intelligence; 
as the study showed, they are far from being successfully implemented. Among the leaders in work in this direction can be identified Moscow, Tatarstan and St. Petersburg. Digital development programs, as a rule, contain an indication of almost the entire range of factors and the possibility of obtaining additional financing for the business that will be involved in its implementation.

[15] I.V. Mitrofanova et al., Digitalization of the economy: world, Russia, region: monograph, Moscow; Berlin: Direct Media, 2019, 72 p.

[16] Kapranova L.D. Digital economy in Russia: state and development prospects, Economics. Taxes. Right. 2018, No. 2, p. 58-69.

[17] Osovin M.N. Analysis of the current state and prerequisites for the development of digital components of the Russian economy, Patterns of development of regional agri-food systems. 2017. No. 1. S. 34-41.

[18] Sukharev O.S. The conditions for the reproduction of human capital in the "digital economy", Electronic resource. Access mode:https://cyberleninka.ru/article/n/usloviyavosproizvodstva-chelovecheskogo-kapitala-v-tsifrovoyekonomike/viewer

[5] Mincer, J. Investment in Human Capital and Personal Income Distribution, Journal of Political Economy, 1958, Vol. 66, No. 4, P. 281-302.

[6] Thurow, L. C. Investment in Human Capital, 1970.

[7] A. I. Dobrynin, S. A. Dyatlov, E. D. Tsyrenova. Human capital in a transitive economy: formation, evaluation, efficiency of use, SPb. : Science, 1999.

[8] Dyatlov, S. A. Human capital of Russia: problems of efficiency of use in a transition economy, $\mathrm{SPb}$. : SPbSUEF, 1995.

[9] Ilyinsky, I.V. Competitiveness of the Russian human capital: state, problems, prospects, $\mathrm{SPb}$. : SPSUTD, 2011.

[10] Klimov, S. M. Intellectual resources of society / S. M. Klimov. - SPb. : Institute of Foreign Economic Relations, Economics and Law, Knowledge, 2002.

[11] Korneychuk, B.V. Human capital in the time dimension, $\mathrm{SPb}$. : Publishing House of the St. Petersburg State Polytechnic University, 2003.

[12] Kritskii, M. M. Human Capital, L.: Publishing house of Leningrad State University, 1991.

[13] Simkina, L. G. Human capital in an innovative economy, $\mathrm{SPb}$. : St. Petersburg State Academy of Engineering and Economics, 2000.

[14] Uskov Vrussian industrial sector development in the context of new technological revolution, Economic and social changes: facts, trends, forecast, T. 2, № 2, 2019, 128-146.
[19] Chukhno A. New economic policy, Economy of Ukraine. - 2005. - No. 5. - P. 15-22.

[20] Kazakov O.D., Azarenko N.Yu. Human capital management model in decision-making systems, Bulletin of Voronezh State University of Engineering Technologies. 2019. Vol. 81. No. 3. P. 290-298. doi: 10.20914 / 2310-1202-2019-3-290-298

[21] Ryazantsev S.V., Pismennaya E.E. Emigration of scientists from Russia: "Circulation" or "brain drain", Sociological studies. 2013. No. 4. P. 24-35.

[22] Baskakova M.E., Soboleva I.V. The core of the digital economy in the light of globalization risks, Bulletin of the Institute of Economics of the Russian Academy of Sciences. 2019, No 2.P. 81-92.

[23] Russia 2025: from personnel to talent / http://drussia.ru/wpcontent/uploads/2017/11/Skills_Outline_web_tcm26175469.pdf

[24] Regions of Russia. Socio-economic indicators [Electronic resource], Federal State Statistics Service. Access mode: Ahttp://www.gks.ru/bgd/regl/b16_14p/Main.htm 